\title{
Strategic Architecture in Poultry Company
}

\author{
Erlinda Oktavia ${ }^{\bowtie}$, Marimin, Setiadi Djohar
}

Postgraduate School of Business, Bogor Agriculture University, Bogor, Indonesia

Info Article

History Article:

Received Juni 2017

Approved August 2017

Published September 2017

Keywords:

Industry Foresight; Poultry

Industry; Strategic Architecture;

Strategic Planning.

\begin{abstract}
The purpose of this study is to identify factors in the external environment affecting the poultry industry, analyze the business integration process of the company and know its internal factors, analyze the future of the poultry industry in Indonesia and formulate the strategic architecture of PT Sierad Produce Tbk (SIPD) and its priority importance. Respondents in this study were determined using purposive sampling method. While the research method used is descriptivequalitative with case study approach and using Analytical Hierarchy Process (AHP) as priority determination of interest.. The results of the research are several alternative SIPD strategy based on the main objective of the company, that is maximizing corporate integration, product development and market development. A strategic map as a strategic architecture design lane is created to illustrate the execution time of each alternative strategy. The business integration process at SIPD is currently not optimally developed, meaning that every stage of the production process is still a profit center.
\end{abstract}

\section{Arsitektur Strategik pada Perusahaan Perunggasan}

\begin{abstract}
Abstrak
Tujuan penelitian ini adalah mengidentifikasi faktor pada lingkungan eksternal yang memengaruhi industri perunggasan, menganalisis proses integrasi bisnis perusahaan dan mengetahui faktor internalnya, menganalisis tinjauan masa depan industri perunggasan di Indonesia, dan merumuskan arsitektur strategik PT Sierad Produce Tbk (SIPD) serta prioritas kepentingannya. Responden pada penelitian ini ditentukan menggunakan metode purposive sampling. Sedangkan metode penelitian yang digunakan adalah deskriptifkualitatif dengan pendekatan studi kasus dan menggunakan Analytical Hierarchy Process (AHP) sebagai penentuan prioritas kepentingan.. Hasil penelitian diperoleh beberapa alternatif strategi SIPD berdasarkan tujuan utama perusahaan, yaitu memaksimalkan integrasi perusahaan, pengembangan produk, dan pengembangan pasar. Peta strategi sebagai jalur rancangan arsitektur strategik dibuat untuk menggambarkan waktu pelaksanaan pada tiap strategi alternatif. Proses integrasi bisnis di SIPD yang saat ini belum berkembang secara optimal, artinya setiap tahap proses produksi masih merupakan pusat keuntungan.
\end{abstract}

JEL Classification: L20, L21, L23

How to Cite: Oktavia, E., Marimin \& Djohar, S. 2017. Strategic Architecture in Poultry Company. Jurnal Dinamika Manajemen. 8 (2): 245-258.

$\begin{array}{lr}{ }^{\boxplus} \text { Correspondence Address } & \text { ISSN } \\ \text { Jalan Raya Pajajaran Bogor } & \text { 2086-0668 (print) 2337-5434 (online) } \\ \text { E-mail: erlindaoktavia@rocketmail.com } & \text { DOI: 10.15294/jdm.v8i2.12764 }\end{array}$




\section{INTRODUCTION}

The poultry industry is growing as the demand for meat increases. World meat consumption in 2030 is projected to increase and chicken meat is estimated to take a portion of $33 \%$ to $38 \%$. In developing countries, poultry consumption is expected to increase to $33.3 \%$, from $10.5 \mathrm{~kg}$ to $14 \mathrm{~kg}$ per capita. In Asia, the increase in poultry consumption per capita per year is estimated to reach $2.9 \mathrm{~kg}$. The consumption of chicken meat per capita in Indonesia has increased since 2005 until 2015 (Pusdatin, 2015).

High consumption of chicken meat is thought to be due to lower chicken prices than other animal meat (Ditjennak, 2014). Unfortunately, the increase in consumption has not been adjusted to the level of production. Indonesia is ranked 10th as a broiler meat producer in the world with a total production of 1,640 million tons and is estimated to increase to 1,660 million tons in 2017 (USDA, 2016).

Besides the increase of income, the increase in chicken meat consumption in Indonesia is also caused by the improvement of education level, as well as the increasing of public awareness of the need for nutrient intake. Increased consumption of chicken meat is also influenced by changes in the lifestyles of consumers who want the convenience around them because time is spent more in the workplace and out- doors, so eating patterns related to foods ready to eat and ready to cook is needed (Bapokstra, 2016). Vertical Integrated Poultry Business (V-IPB) is an ideal strategy to be applied in the broiler business (Daryanto, 2009).

Sierad Produce Inc (SIPD) as a leading food industry based on the integrated poultry industry, maximizes the integration concept that leads to the food industry as a downstream, but the company experienced a decrease in net sales in a row from 2013 to 2016, incurring losses in 2014 and 2015 (Table 1). Despite the loss in 2016 , the company received a positive impact of improved macroeconomic conditions (strengthening of the Rupiah against the US Dollar), which is a percentage increase in net sales from the previous year, mainly from sales of animal feed products (raw material prices) and day-old chicks (increase in selling price). The increase in net sales of SIPD is still considered low, indicating that there is still a problem with the company's business integration process in the face of the current competition (SIPD, 2016).

The integrated companies in the poultry industry listed on the Indonesia Stock Exchange (IDX), namely Charoen Pokphand Indonesia (CPIN), Malindo Feedmill (MAIN) and SIPD show the largest net sales figures in livestock feed (upstream), while JPFA managed to achieve the largest net sales result in the final product downstream, namely chicken meat

Table 1. Net sales of PT Sierad Produce Tbk (billion rupiah)

\begin{tabular}{lrrrrr}
\hline \multicolumn{1}{c}{ Information } & $\mathbf{2 0 1 2}$ & $\mathbf{2 0 1 3}$ & \multicolumn{1}{c}{$\mathbf{2 0 1 4}$} & \multicolumn{1}{c}{$\mathbf{2 0 1 5}$} & $\mathbf{2 0 1 6}$ \\
\hline Net sales & $4,354.47$ & $3,854.27$ & $2,505.58$ & $2,113.15$ & $2,427.20$ \\
$\begin{array}{l}\text { Percentage of sales from previ- } \\
\text { ous year }\end{array}$ & - & $-11 \%$ & $-35 \%$ & $-16 \%$ & $15 \%$ \\
Gross profit & - & & & & \\
(Loss) on Operating Income & - & 1486.64 & 378.00 & 184.20 & 441.90 \\
\hline
\end{tabular}

Table 2. Net Sales of Poultry Companies (Listed on IDX) in 2015 (Billion Rupiah)

\begin{tabular}{lrrrrrr}
\hline Information & Animal feed & \multicolumn{1}{c}{ DOC } & Broilers & Processed Food & Etc. & Total Net Sales \\
\hline CPIN & $21,978.5$ & $3,713.6$ & 35.5 & $3,120.7$ & $1,072.4$ & $29,920.6$ \\
JPFA & 9,210 & 1,510 & 1,120 & 10,270 & $2,912.9$ & $25,022.9$ \\
SIPD & 1,097 & 478 & 139 & 399 & - & $2,113.2$ \\
MAIN & $3,316.1$ & 861.9 & 424.4 & 61.2 & 111.5 & 4,775 \\
\hline
\end{tabular}


Erlinda Oktavia, et al. / Strategic Architecture in Poultry Company...

and processed chicken (Table 2). This indicates that opportunities to improve competitiveness in chicken and processed chicken business segments are still open to companies (SIPD) but require a competitive strategy plan in achieving business success.

Strategic architecture is the design of competitive strategies that can be applied to poultry companies, namely the development of business based on the internal strength of the organization (core competency) and rebuild industry boundary that will be entered in the future (industry foresight). Hamel and Prahalad (2000) argue that in competition for the future, companies not only compete within the boundaries of existing industries but also compete to form future industrial structures. The challenge of competing not only requires organizational transformation but also industrial transformation. Strategic architecture can be said an update the concept of strategy formulation (Yoshida, 2006). In addition to strategy formulation, prioritizing strategies should also be undertaken, ie using AHP weighting. This is based on the statement Markovic (2008) and Putri and Yuniawan (2016) that the key factors in the success of change are the ability of leadership and managerial, namely visioning, determining priorities, planning, receiving feedback and appreciation.

This research is based on several previous studies such as that of Widodo et al. (2008). The research aims to map the company's position in the paint industry competition, analyze the competencies of PT Sigma Utama and the competencies to be developed and develop strategic architecture for the next 10 years. This research uses the descriptive method, that is external and internal analysis with AHP method. Respondents were determined by purposive sampling.

Rismon (2010) conducted research on strategic architecture of Perum Pegadaian with the descriptive method through case study and using purposive sampling. The purpose of this study is to identify the factors that influence the existence of Perum Pegadaian, analyze the current competencies and competencies that will be developed in the future and develop strategic architecture.

Research conducted by Dugo (2011) and David et al. (2016) on strategic architecture using descriptive analysis method to business environment (internal and external), analysis of future industry review and design of the strategic architecture of PT Petrokimia Gresik 2010-2020 which then continued with priority setting through AHP. The aims of this research are (1) to identify factors in the external environment affecting the poultry industry, (2) to analyze the current business integration process and knowing the internal factors, (3) to analyze the future of the poultry industry in Indonesia and (4) to formulate the strategic architecture of Sierad Produce Inc and its priority interests.

\section{Poultry Industry in Indonesia}

Livestock subsector in Indonesia has great potential to be developed because it has a comparative advantage (Deblitz et al., 2005). The comparative advantages of Indonesia's livestock sub-sector include the potential of livestock resources, natural resources in providing feed and low labor costs (Daryanto, 2009). Poultry is one of the livestock sub-sector commodities which since 1972 experienced relatively rapid growth. The growth is driven by strong growth from the upstream industry sector (feed, nursery and pharmaceutical industries) and downstream industries which include chicken slaughterhouses, restaurants and others. The most dominant poultry farming business and considered the most attractive to be cultivated is broiler agribusiness.

Cultivation or poultry production undergoes a shift from farming to traditional commercial farms (Windhorst, 2006). Broiler sub-sector is the subsector that is considered the best performance compared to the other three subsectors. This is based on the continuous increase of chicken production from year to year so that in 2010 has been able to meet national needs.

Poultry production is influenced by several external factors, according to Tangendjaja (2010) influencing factors in the production 
of poultry (broiler), the fulfillment of the need for corn, the use of latest technology, experience in exporting, vertical integration nationally and support from the government. Saptana and Sumaryanto (2009) mentioned the external factors in poultry growth are population and growth rate, income increase, urbanization rate, quality and product development (market segmentation phenomenon) and consumer preference.

The growth of poultry is also determined by the development of cultivation technology, genetic development, concentrated genetic base, grain prices and distribution of its use and feed category. Meanwhile, according to Saptana and Daryanto (2013), the factors that influence, among others, population, income level, urbanization phenomenon, market segmentation and consumer preference and economy of scale and productivity growth factor, technological change and technical efficiency. Increased consumption of chicken meat in Indonesia is also due to increased income, improved education levels and increased public awareness of the need for nutritional intake (Pusdatin, 2015).
Nurfadillah (2015) added that demand for chicken meat products will always increase due to several factors, namely first, demographic changes in the form of population growth and revenue growth. Second, lifestyle changes cause the demand for ready to cook and ready to eat increases. Third, the increasing number of QSR (Quick Service Restaurant), supermarkets and hypermarkets offering a variety of commodities and processed products of chicken meat. Fourth, more and more consumers are linked to health reasons switching from red meat to chicken meat. Fifth, chicken meat has a role as a provider of animal protein is the cheapest compared with other farm commodities.

\section{Strategic Architecture}

Strategic architecture is basically a dynamic and flexible approach to strategic planning and a solution to the rapidly changing business environment. Differences in strategic planning with strategic architecture can be seen in Table 3 .

Strategic architecture is basically a highlevel blueprint for the deployment of new functionality, the acquisition of new competencies

Table 3. Differences in Strategic Planning and Design of Strategic Architecture

\begin{tabular}{|c|c|c|}
\hline & Strategic Planning & Strategic Architecture \\
\hline $\begin{array}{l}\text { Purpose of } \\
\text { Planning }\end{array}$ & $\begin{array}{l}\text { Incremental increase in market share } \\
\text { and position }\end{array}$ & $\begin{array}{l}\text { Change the rules of the industry and create } \\
\text { new competitive space }\end{array}$ \\
\hline Planning & Formal and ritualistic & Exploratory and open \\
\hline Process & $\begin{array}{l}\text { Existing industry and market struc- } \\
\text { ture as the foundation } \\
\text { Analysis of industrial structure (seg- } \\
\text { mentation analysis, value chain analy- } \\
\text { sis, cost structure analysis, competitor } \\
\text { alleged plotters, etc.) } \\
\text { Examination of suitability between } \\
\text { resources and plans } \\
\text { Capital budgeting and resource allo- } \\
\text { cation among competing projects } \\
\text { Individual businesses as a unit of } \\
\text { analysis }\end{array}$ & $\begin{array}{l}\text { Understanding of discontinuity and compe- } \\
\text { tence as the foundation } \\
\text { Search for new functions or new ways of } \\
\text { delivering traditional functions } \\
\text { Enlarge the opportunity horizon } \\
\text { Examination of interest and timeliness of } \\
\text { new opportunities } \\
\text { Development of plans for acquisition and } \\
\text { migration of competencies } \\
\text { Development of plans to approach opportu- } \\
\text { nities } \\
\text { Corporations as a unit of analysis }\end{array}$ \\
\hline Resource & Executive business unit & Many managers \\
\hline Planning & $\begin{array}{l}\text { Some experts } \\
\text { Staff oriented }\end{array}$ & $\begin{array}{l}\text { The company's collective wisdom } \\
\text { Staff and line oriented }\end{array}$ \\
\hline
\end{tabular}


or migration of existing competencies and customer interface reconfiguration (Hamel \& Prahalad, 2000; David et al., 2016). Strategic architecture application step begins with an analysis of the external and internal environment and the industry foresight is set which is the industry restrictions to be entered into the organization in the future, then can be prepared strategic challenges facing the organization. Finally, the strategy is formulated by pouring in the form of strategic map (Blueprint strategy) (Yoshida, 2006; Krzyżanowska \& Tkaczyk, 2015; Farida, 2016).

\section{Industry Foresight}

The industry foresight review is the best mutually agreed assumption about the future of an industry/ company/ organization and based on this it builds everything necessary to support the evolution of the business by delving deeply into the drivers of the industry. Industry foresight provides an overview of the potentials in the company/organization to be developed in the future and allows the company/ organization to take a leadership position (Hamel \& Prahalad, 2000; Sugianto \& Hartono, 2017).

\section{METHOD}

The method used in this research is the descriptive-qualitative method through case study and using AHP (Analytical Hierarchy Process) as its weighting. SIPD is determined as a research object because it is the only company experiencing a downward trend in net sales (2012-
2016) and even experienced losses in 2014 and 2015, among other the integrated companies in the poultry industry listed on the Indonesia Stock Exchange (IDX), namely Charoen Pokphand Indonesia (CPIN) and Malindo Feedmill (MAIN). The data used in this study are primary data and secondary data. The technique of collecting data and information in this research is by using in-depth interview (direct interview), direct observation (observation), questioner and literature study done by reading document, literature, scientific writing and various other library materials related to the writing of this thesis.

Determination of respondents using purposive sampling. According to Marimin (2004) criteria to be the basis of consideration for determining or selecting experts to be respondents (internal and external respondent). Determined 7 respondents in this study, which are 4 internal respondents and 3 external respondents, among others Drh Sudirman MM (Business Development Director), Dr Ir Yunus Triyonggo, MM, CAHRI (Chief of Human Capital Development), Setiyanto (HR Businees Partner Poultry), Ading Nurjaman (Internal Control \& Analys Farming), Dr Rudi Afnan, SPt, MscAgr (Lecturer Department of Animal Production and Technology, Faculty of Animal Husbandry, Bogor Agricultural University), Dr Ir Rita Mutia, Magr and Dr Ir Widya Hermana, MSi (Lecturer Department of Nutrition Science and Feed Technology, Faculty of Animal Husbandry, Bogor Agricultural University).

Determination of strategy using strategic architecture analysis tool, that is identification

Table 4. External environmental factors

\begin{tabular}{|c|c|c|c|c|c|c|}
\hline No. & External Factors & 1 & 2 & 3 & 4 & 5 \\
\hline 1. & The population of Indonesia & & $\sqrt{ }$ & $\sqrt{ }$ & $\sqrt{ }$ & $\sqrt{ }$ \\
\hline 2. & Increasing people's income & & $\sqrt{ }$ & $\sqrt{ }$ & $\sqrt{ }$ & $\sqrt{ }$ \\
\hline 3. & Consumer preferences & & $\sqrt{ }$ & $\sqrt{ }$ & & $\sqrt{ }$ \\
\hline 4. & Level of urbanization & & $\sqrt{ }$ & $\sqrt{ }$ & & \\
\hline 5. & Business scale & $\sqrt{ }$ & & $\sqrt{ }$ & & \\
\hline 6. & Availability of raw materials for animal feed & $\sqrt{ }$ & & & & \\
\hline 7. & Support from the government & $\sqrt{ }$ & $\sqrt{ }$ & & & \\
\hline 8. & Technology developments & $\sqrt{ }$ & $\sqrt{ }$ & $\sqrt{ }$ & & \\
\hline
\end{tabular}

Note: 1 (Saptana \& Sumaryanto, 2009); 2 (Tangendjaja, 2010); 3 (Saptana \& Daryanto, 2013); 4 (Nurfadillah, 2015); 5 (Pusdatin, 2015). 
of external environment factor, analysis of business integration process of the company with internal analysis and analysis of industry foresight. The identification of external environmental factors is obtained through the accumulation of literature studies (Table 4). Factors in the external environment were obtained based on the accumulation of literature study from Saptana and Sumaryanto (2009), Tangendjaja (2010), Saptana and Daryanto (2013), Nurfadillah (2015) and Pusdatin (2015). Then obtained eight external factors which then described in descriptive and statistics.

The internal environment is the environment that can be controlled by the company, the factors that can be controlled include the entire business process of the company. The business integration process in the broiler chickens chains covers all business units of the company (Micah, 2011). So the analysis of business integration process of the company in this research is done to know the condition of the company at this time, as well as to know the strength and weakness that exist in the company by considering every business unit of the company.

An analysis of poultry foresight industry considers the results of external and internal analysis of factors and current changes. Industry foresight will help leaders to answer three critical questions: 1) what products are useful and needed by consumers in the next five or ten years, 2) what new competencies are needed to realize the product, 3 ) how to make consumers, for the next few years are willing to abandon the old product and move on to the new product (Hamel \& Prahalad, 2000). The results of the analysis of the poultry industry foresight then referenced to determine alternative strategies and objectives of the company.

The use of AHP according to Palma et al. (2014) is undertaken to distinguish the degree of importance between multiple supply chain processes in the use of multi-criteria decision analysis as decision supporters in the selection process. In this study, AHP (Analytical Hierarchy Process) method is used as a decision sup- port to differentiate the priority interests of each analysis on the strategic architecture. Strategic architecture design formulated into a four-level hierarchy of AHP consisting of external actors, industry foresight, the company's objectives and alternative strategies. AHP weighting through pairwise comparison techniques using software Expert Choice 11.

The resulting strategic priorities through AHP is not a process to select a strategy and also not show the timeline of implementation of the strategy on strategic architectural design. Priority strategy shows the ability of each strategy to meet the objectives of the previous level which in its implementation is influenced by limited resources. Finally, determine corporate strategic challenges for the design of strategic architecture can be achieved. Strategic challenges serve as a basis for determining the timing of the execution of each alternative strategy. Strategic architecture is formulated by pouring in the form of strategic map drawing (strategy map) with the timeframe. The framework of this research is shown in Figure 1.

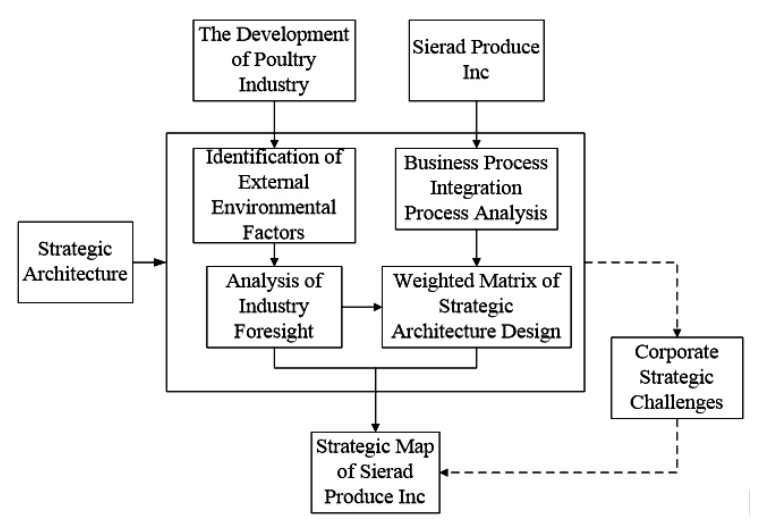

Figure 1. Research Framework

\section{RESULT AND DISCUSSION}

\section{Identification of External Environment Factors}

Factors in the external environment were obtained based on the accumulation of literature studies, ie eight external factors that were then identified descriptively and statistically (Table 5), among others, the population of indonesia, increasing people's income, consumer 
Erlinda Oktavia, et al. / Strategic Architecture in Poultry Company...

preferences, level of urbanization, availability of raw materials for animal feed, support from the government and technology developments.

\section{The population of Indonesia}

Indonesia ranks first in ASEAN as the world's fourth largest and fourth in the world with 255 million inhabitants based on the results of the 2010 census. The projected population of Indonesia over the next twenty-five years continues to increase, from 238.5 million in the year 2010 to 305.6 million in 2035 . The large population is a potential consumer for the poultry industry (BPS, 2013).

\section{Increasing People's Income}

The rapid growth of the middle class in Indonesia according to Mc Kinsey Global data is 45 million people and will increase to 135 million by 2030 (BPS, 2013). Middle-class growth indicates an increase in people's incomes. Increased public incomes have an impact on the increasing demand for chicken meat in Indonesia. The prediction of the chicken meat balance in
Indonesia for the year 2015-2017 will experience an average surplus of about 37.40 thousand tons, while in 2018 and 2019 estimated deficit of 11.67 thousand tons and 30.93 thousand tons. People who experience increased revenue make the demand for products increasingly complex (Pusdatin, 2015).

\section{Consumer Preferences}

The share of food expenditures for finished food/ beverages, both in the city and in the village has increased. This trend is made possible by lifestyle changes that impact on dietary changes. Integrated companies are developing not driven by supply (driven) but by consumer demand (consumer driven) (Tangendjaja, 2010).

\section{Level of Urbanization}

The percentage of Indonesians living in Java continues to decline from about $57.4 \%$ in 2010 to $54.7 \%$ in 2035 . In contrast, the percentage of people living on other islands increased, as Sumatra Island increased from $21.3 \%$ to $22.4 \%$, $5.8 \%$ to $6.6 \%$ in the same period (BPS, 2013).

Table 5. Identification of External Environmental Factors

\begin{tabular}{|c|c|c|c|}
\hline No. & $\begin{array}{c}\text { External } \\
\text { Factors }\end{array}$ & $\begin{array}{l}\text { Opportuni- } \\
\text { ties/ Threat }\end{array}$ & The identification results \\
\hline 1. & $\begin{array}{l}\text { The population } \\
\text { of Indonesia }\end{array}$ & Opportunities & $\begin{array}{l}\text { Indonesia's first largest population in ASEAN (BPS, 2013) } \\
\text { and low consumption of chicken meat (USDA, 2016) }\end{array}$ \\
\hline 2. & $\begin{array}{l}\text { Increasing } \\
\text { people's income }\end{array}$ & Opportunities & $\begin{array}{l}\text { There has been increased demand for chicken meat in In- } \\
\text { donesia and the demand for increasingly complex products } \\
\text { (Pusdatin, 2015) }\end{array}$ \\
\hline 3. & $\begin{array}{l}\text { Consumer pref- } \\
\text { erences }\end{array}$ & Threat & $\begin{array}{l}\text { The existence of changes in consumer lifestyles (Tangendjaja, } \\
\text { 2010) }\end{array}$ \\
\hline 4. & $\begin{array}{l}\text { Level of urban- } \\
\text { ization }\end{array}$ & Opportunities & $\begin{array}{l}\text { The declining percentage of Indonesians living in Java and } \\
\text { the increasing percentage of people living on other islands } \\
\text { (Sumatera and Kalimantan) (BPS, 2013) }\end{array}$ \\
\hline 5. & Business scale & Threat & $\begin{array}{l}\text { The increase in population and the production of broilers and } \\
\text { implementation of optimal vertical integration (Pusdatin, } \\
\text { 2015) }\end{array}$ \\
\hline 6. & $\begin{array}{l}\text { Availability of } \\
\text { raw materials for } \\
\text { animal feed }\end{array}$ & Threat & $\begin{array}{l}\text { Fluctuations in the rupiah exchange rate (Bapokstra, 2016) } \\
\text { and the cost of shipping logistics raw material (GPMT, 2014) }\end{array}$ \\
\hline 7. & $\begin{array}{l}\text { Support from } \\
\text { the government }\end{array}$ & Opportunities & $\begin{array}{l}\text { Efforts to increase chicken meat consumption and infra- } \\
\text { structure improvements (Kemendag, 2017) }\end{array}$ \\
\hline 8. & $\begin{array}{l}\text { Technology } \\
\text { developments }\end{array}$ & Opportunities & $\begin{array}{l}\text { Technological development and cold chain development } \\
\text { (Saptana \& Daryanto, 2013; Poultry Indonesia, 2016) }\end{array}$ \\
\hline
\end{tabular}




\section{Business Scale}

The Large business scale is one of the advantages of a vertically integrated company. Business consolidation should be continuously upgraded to become an efficient and competitive poultry company with the application of vertical integration. Production of chicken meat in the period 2011-2015 fluctuates and tends to increase with the average growth of broiler breeding rate of $6.05 \%$ per year and laying chicken of $11.03 \%$ per year (Pusdatin, 2015).

\section{Availability of Raw Materials for Animal Feed}

Indonesia has an advantage in the procurement of raw materials of animal feed. Sixty to $70 \%$ of the main feedstock feed industry is corn and soybean meal in which about $40 \%$ of maize is still imported and soybean meal is still imported. The price of chicken meat at the end of 2015 and early 2016 continues to increase so as to suppress the purchasing power of the people and reduce the level of chicken meat consumption. This is the same with the price of corn, the increase of corn prices at the end of 2015 is suspected as a result of the sudden cessation of corn imports because it is perceived that the domestic corn production has fulfilled the need (Bapokstra, 2016).

Another aspect to consider is the relatively low cost of logistics in Indonesia. Based on information from GPMT, the cost of corn delivery per $\mathrm{kg}$ from Sulawesi Island to Java Island is equal to the cost of corn imports (per kilogram) from the United States (GPMT, 2014).

\section{Support from the Government}

The assessment of Indonesia's infrastructure condition got the fourth position in the ASEAN region after Singapore, Malaysia and Thailand. Based on the results of the Global Logistics Performance Index (LPI) in 2016 which shows that Indonesia is ranked 63rd out of 160 countries monitored with a score of 2.98 . The number is down from a score of 3.08 in 2014 and is ranked 53rd. So the government is currently seeking acceleration of infrastructure development, especially to support the improve- ment of logistics activities in order to improve the competitiveness of national products in the global market (Kemendag, 2017).

\section{Technology Developments}

Technological developments in increasingly modern production processes, enabling shorter production cycles (faster growth and lower mortality), lower FCR (Feed Conversion Ratio) and more integrated poultry production systems. While the development of technology in the current marketing aspect by seeking optimization of technology utilization in the field of communication through e-marketing (Bradley et al., 2011; Bradley et al., 2012; Poultry Indonesia, 2016). Efforts to integrate products and between business actors and avoid disease outbreaks can be done with the enactment of the latest policies that need to be applied in Indonesia, namely through the development of cold chain (Saptana \& Daryanto, 2013; Siebers et al., 2013).

\section{Corporate Business Integration Process Ana- lysis}

Sierad Produce Inc (SIPD) is one of the perpetrators of vertical integration based on the poultry industry. The poultry industry consists of upstream industries (feed factories, nurseries and pharmaceutical industries) and downstream industries that include chicken slaughterhouses, restaurants and others. The business units run by SIPD, namely animal feed factory, breeding farm (Day Old Chick or DOC), commercial farm (chicken broiler), chicken slaughterhouse and processed foods. The SIPD business integration process begins with the breeding farm business unit that provides day-old chicks (DOC) to commercial farm for cultivation and fattening. An adult chicken from the commercial farm is distributed to the chicken slaughterhouse for cutting into a partially processed carcass into boneless and parting meat to serve as raw material for making processed chicken food (nuggets). While the animal feed factory acts as a feed supplier on breeding farms and commercial farms.

According to Tangendjaja (2010) and Dehbokry and Chew (2015), vertical integra- 
tion is said to develop if major profit is derived from the further processing and each business unit in the integration process is only part of the process to produce meat or eggs instead of being a stand-alone company. Each process is considered a cost center rather than a profit center. Pefindo (2009) and Fjeldstad (2012) added that companies with vertical integration systems can coordinate the utilization capacity of each stage of production and can control the quality from the beginning to the end.

Based on the problems that occur in the SIPD business integration process, it can be said that industrial or vertical integration is still not developed, that is a matter concerning the acquisition of added value, the aspect of quality safety and nutrition of food. Some of the problems that occur in the SIPD business integration process, which is the company's weakness namely the process of integration of SIPD every stage of the production process or each business unit is still a profit center or still in fragmented business and the livestock feed business unit is currently a major contribution to the acquisition of SIPD's profit with a sales value of 50\% of total net sales of the company (Table 6). Although the food produced is consumed for its own farming purposes, some of it is sold to free markets, either directly to farmers, through independent farmers (who own plasma breeders), or through poultry shops.

The other problems that occur in the SIPD business integration process, which is the company's weakness are commercial farm business unit, SIPD is still selling live chickens (livebird). Sales of live chickens are due to the condition of chicken weight that has not met the requirements of chicken house raw materials. In addition, the sale of live chickens is considered to have many shortcomings, including live chicken prices, always fluctuate following the market, considered inefficient because it can not last long, there is the risk of death during the trip sales, as well as the spread of livestock disease.

The last problem that occur in the SIPD business integration process are about the chicken slaughtering business unit, in fulfilling the raw materials SIPD uses $40 \%$ of its own integration chain, while to meet $60 \%$ of SIPD chicken supply raw materials buy from outside its integration chain. This shows that the fulfillment of raw materials of chicken houses owned by the company has not been fully organized, ie less optimal management of commercial chicken farming, the lack of availability of chicken supply for the long-term sustainability and adjustment of chicken quality standards (on-farm, feed, hygiene and chicken health). The end product of the chicken slaughterhouse business unit has not yet applied labeling, whereas according to McMillin et al. (2012) high production figures should be supported with an ability to track and monitor the product, feed, production of pet food or ingredients, as well as all stages of production and distribution.

While the strength of the company is a chicken-cutting facility with an installed production capacity of 100000 chickens per day and application of an international standard cultivation system.

\section{Analysis of the Poultry Industry Foresight}

In general, respondents expressed their views on trends or future changes by answering

Table 6. SIPD Net Sales per Business Unit

\begin{tabular}{lrcrc}
\hline \multicolumn{1}{c}{ Description (in billion) } & $\mathbf{2 0 1 6}$ & Percentage & $\mathbf{2 0 1 5}$ & Percentage \\
\hline Animal feed & 1,215 & $50, \%$ & 1,097 & $51.9, \%$ \\
Day Old Chick (DOC) & 384 & $15.8, \%$ & 255 & $12.1, \%$ \\
Broilers & 206 & $8.5, \%$ & 212 & $10, \%$ \\
Chicken farm & 281 & $11.6, \%$ & 150 & $7.1, \%$ \\
Etc. & 341 & $14.1, \%$ & 399 & $18.9, \%$ \\
Total Net Sales & $2,427.20$ & $100 \%$ & $2,113.15$ & $100 \%$ \\
\hline
\end{tabular}


three critical questions (Hamel \& Prahalad, 2000; Yang \& Lynn, 2014), among others: what products are useful and needed by consumers in the next five or ten years? the final product to be offered in the future that benefits the customer, including no sales of live chickens (livebird) from commercial farms, new standards of re-branding dress chicken, ready-to-eat chicken products and raw materials (chicken) using natural growth promoters in place of antibiotics;

What new competencies are needed to realize the product? New competence to be applied for the improvement of company quality, that is development of niche-market product for high-quality product with high price, adoption of the technology update (international standard quality) and professional human resources, animal raw material fulfillment only from chain integration (compliance with quality standards on product safety), use of video conference media, development of supply cold chain management as a supplier of traditional markets, deve- loping traceability attributes to end customers and networking through the Academic, Business, Community, Government (ABCG) approach;

How to keep consumers, for the next few years willing to leave the old product and move on to the new product? Access to the network to be interfaced with the customer is to create an entrepreneur new, improving customer business, providing information and serving customers via the internet (e-commerce), as well as creative marketing and customer relationship oriented.

The results of industry foresight's analysis then become alternative SIPD strategies categorized based on three main objectives of the company, namely maximizing corporate integration, product development and market development. Hamel dan Prahalad (2000) states that a competence (a company's strength) can be considered a core competency if it meets three criteria, that is value for the customer (customer value), has competing differentiation or is not easily imita-

Table 7. Corporate Strategic Challenges and Year of Implementation

\begin{tabular}{lllc}
\hline \multicolumn{1}{c}{$\begin{array}{c}\text { Company's } \\
\text { objectives }\end{array}$} & \multicolumn{1}{c}{ Alternative Strategies } & $\begin{array}{c}\text { Corporate strate- } \\
\text { gic challenges }\end{array}$ & $\begin{array}{c}\text { Year } \\
\text { begin }\end{array}$ \\
\hline $\begin{array}{l}\text { Maximizing the } \\
\text { integration of the } \\
\text { company }\end{array}$ & $\begin{array}{l}\text { Improvement of commercial farm facilities } \\
\text { Human resources training and livestock } \\
\text { farming management }\end{array}$ & $\begin{array}{l}\text { Investment costs } \\
\text { Human Resources }\end{array}$ & 2017 \\
& $\begin{array}{l}\text { The addition of commercial farms } \\
\text { Utilization of video conference media }\end{array}$ & Investment costs & 2017 \\
& Livebird sales conversion into chicken & Networking access & 2021 \\
& carcass & & \\
\hline Product develop- & Trademarking (re-branding) & Consumer awareness & 2022 \\
ment & R\&D development & Investment costs & 2022 \\
& Reduced antibiotic use in broiler & Consumer awareness & 2022 \\
\hline Market develop- & Entrepreneurship development & Networking access & 2017 \\
ment & Implementing e-commerce & Human Resources & 2019 \\
& Utilization of social media & Consumer awareness & 2019 \\
& In cooperation with relevant agencies & Networking access & 2020 \\
& Application of product traceability & Investment costs & 2021 \\
& Other institutional cooperation develop- & Networking access & 2022 \\
& ment & & \\
& Provision of cold storage for traditional & Investment costs & 2022 \\
& markets & & \\
\hline
\end{tabular}


ted by the competitor and can be extendability. Based on the results of literature review and interviews to internal respondents, three core competencies are currently held by SIPD, obtained large-scale chicken cutting facilities (the largest chicken slaughter facility in Indonesia), human resources training programs-based academic (Sierad Academy in collaboration with the Bogor Agricultural Institute) and internationally standardized cultivation system (biosecurity, HACCP application, ISO series) and halal certificate (Putri et al., 2017). The willingness to pay consumers for chicken meat is influenced by the awareness of the importance of halal certification. The core competencies currently owned by SIPD can support the success of the company's core objectives.

\section{Corporate Strategic Challenges}

Business challenges faced by SIPD in the achievement of strategy, including human resources, investment costs, consumer awareness and networking access. Strategic challenges serve as a basis for determining the timing of the execution of each alternative strategy, in detail presented in Table 7. The strategic architecture of the SIPD period 2017-2027 is illustrated in the form of a strategic map that provides information on alternative strategies based on the company's three main objectives along with their implementation timetables (Figure 2).

\section{Weighted Matrix of Strategic Architecture with} AHP

The design of strategic architecture in the AHP hierarchy structure consists of 4 levels, sequentially, external actors, industry future views, company main objectives and alternative strategies, in detail can be seen in Figure 3. Consumers play the most important role in the implementation of strategic architecture based on the highest value of external actors, that is 0.512 . Criteria foresight industry, which is beneficial for the customer and the interface with the customer have an important priority equal to the weight value of 0.455 . Both of these criteria is greater than the weight value competence criteria that have a value of 0.091 .

Product development is the main objective of the company that has the highest value

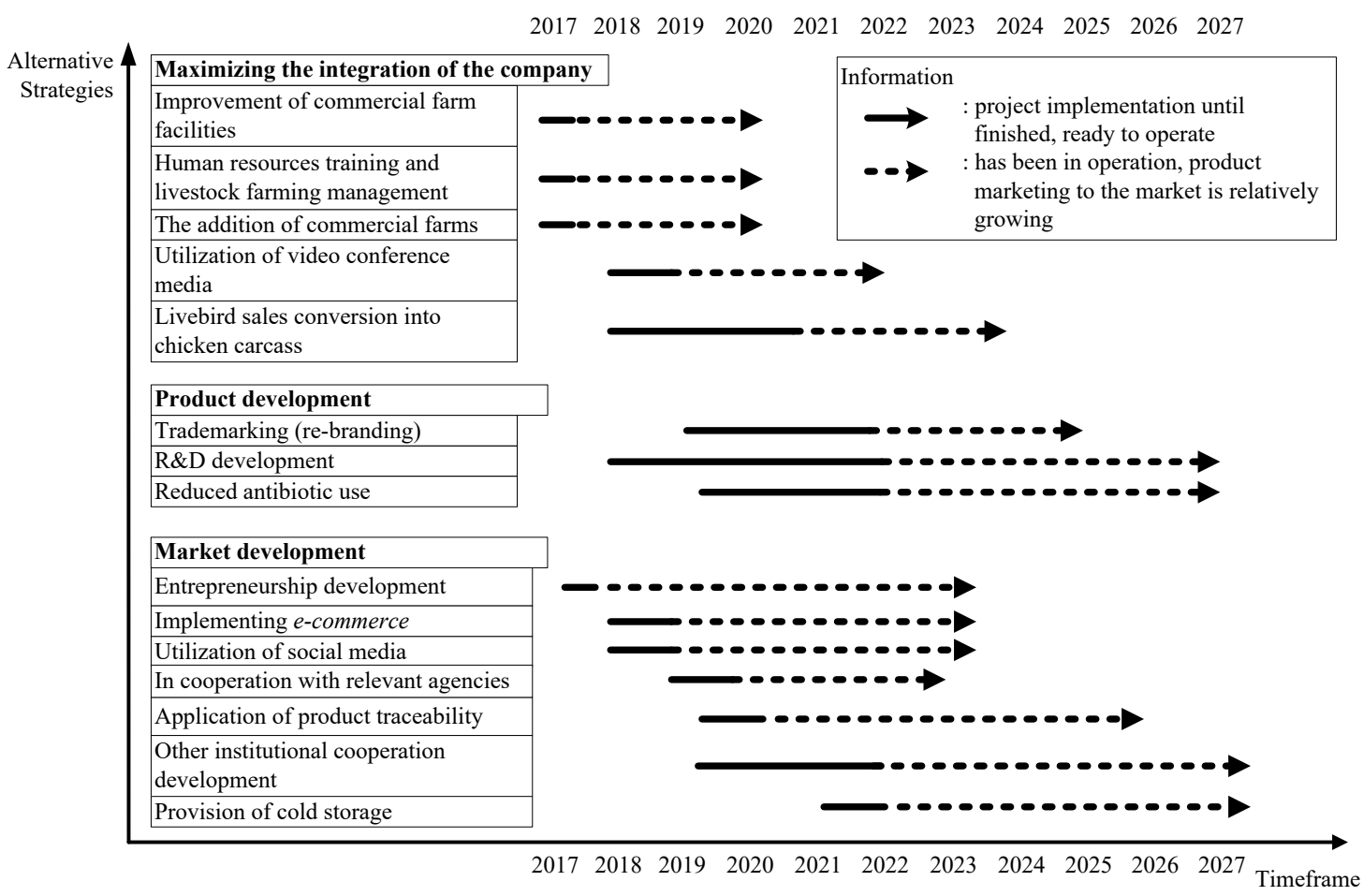

Figure 2. Strategic Architecture of SIPD 2017-2027 


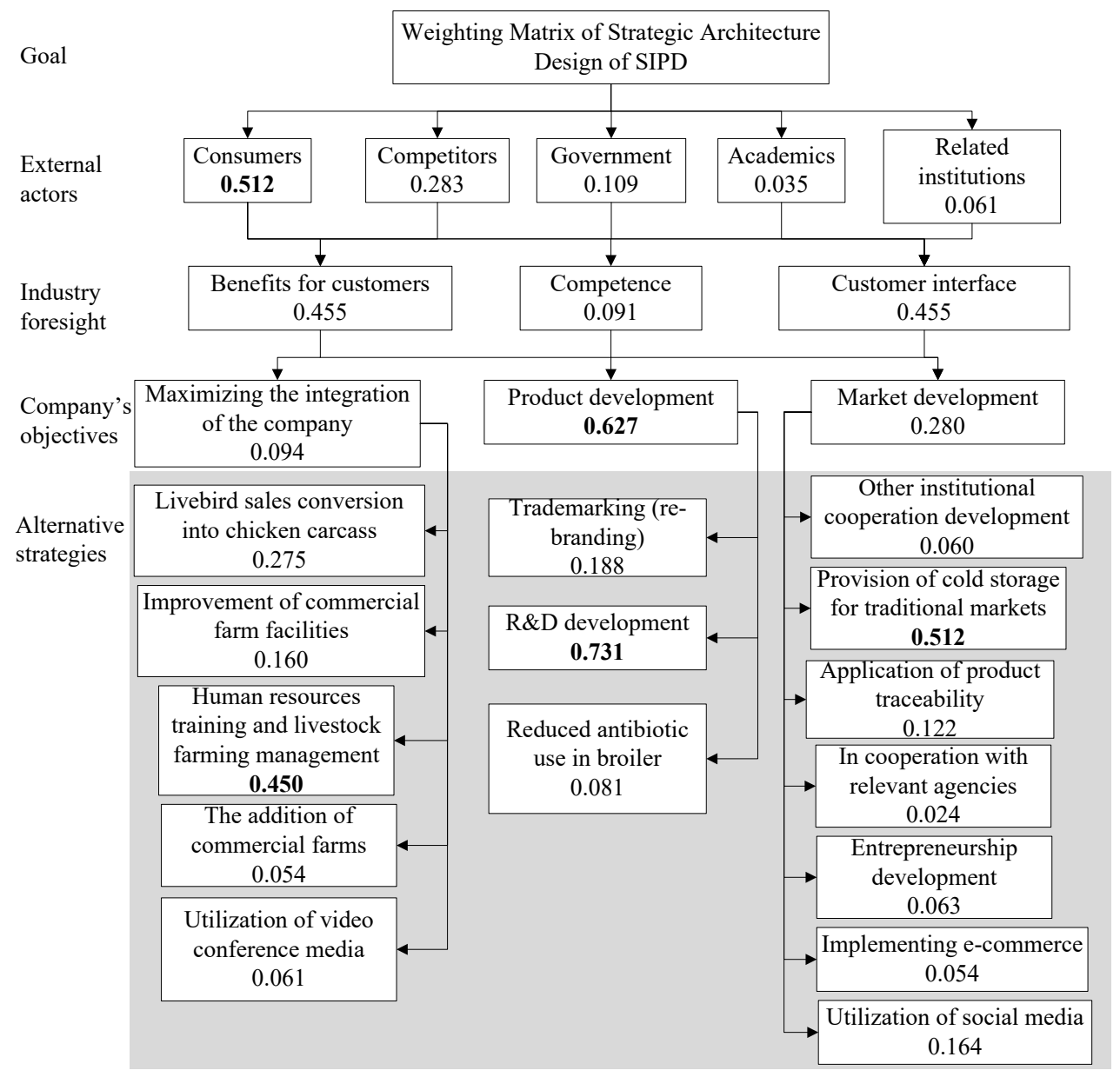

Figure 3. Weighting Matrix Results of SIPDs Strategic Architecture

of 0.627 . The main priority priorities on the strategic alternatives based on their respective company's objectives are respectively based on high to low value, among others the development of R \& D (0.731), provision of cold storage for traditional markets (0.512), as well as human resource training and cultivation management (0.450).

\section{CONCLUSIONAND RECOMMENDATION}

The design of a strategic architecture that has been formulated can be a reference for companies in business development. The process of business integration in SIPD is currently industrial or vertically integrated has not developed optimally, meaning that every stage of the production process is still a profit center. The achievement of institutional markets (hotels, quick service restaurants, catering) with contractual approach proved to ensure product continuity. So the development of niche-market products by developing more institutional cooperation including education, health (hospital, special needs), sports (athletes), government (military, police), will be an advantage that only SIPD has among its competitors. While cooperation with relevant agencies needs to be done through the approach of Academic, Business, Community, Government (ABCG) which will create the benefits of joint in order to achieve social and economic progress.

Suggestions can be given, among others, companies need to conduct controlling in the application of strategic architecture and involve various parties, namely the internal parties (main actors) and external parties (government, academia and related institutions). Some of the 
Erlinda Oktavia, et al. / Strategic Architecture in Poultry Company...

limitations in this study, is the problems that exist in each business unit are analyzed based on a comprehensive report of the company's business processes (commercial farm business unit, chicken slaughterhouse and processed food) and does not consider financial analysis. So the suggestions for further research need to perform a specific analysis on each business unit as well as consider financial analysis in preparing the company's strategy design.

In the implications of strategic architecture, companies can take advantage of opportunities and anticipate threats from external factor analysis, by looking at the weaknesses and strengths of firms derived from the analysis of the company's business integration process. The results of the industry foresight analysis obtained the latest trends or changes which later became the basis for determining alternative strategies of SIPD. SIPD strategy alternatives are categorized into three main objectives of the company, namely maximizing corporate integration, product development and market development.

Companies need to consider the needs and desires of consumers (as the highest priority of interest to external actors) in product development efforts (as a priority of the main interest in corporate goals). Beneficial for customers and interfaces with customers is a priority of higher importance on the criteria of future review with an equal weight value. While on the alternative strategy based on the three goals of the company, respectively according to the value of high to low weight, among others the development of $\mathrm{R}$ $\& \mathrm{D}$, the provision of cold storage for traditional markets, as well as human resource training and cultivation management.

The strategic architecture of SIPD (a period of 10 years) is depicted in the strategy map with the implementation timetable for each alternative strategy. Through strategic architecture, SIPD can enhance competitiveness by creating an internal strength of the organization among other competitors in the poultry industry. Implementation of SIPD's strategic architecture begins with internal company improvements, namely human resources and investment cost allocation. Furthermore, the company runs programs to increase consumer awareness and build network access.

\section{REFERENCES}

BPS. 2013. Indonesia Population Projection 20102035. Jakarta: Badan Perencanaan Pembangunan Nasional.

Bapokstra. 2016. Chicken Price Fluctuation. Buletin Direktorat Barang Kebutuhan Pokok dan Barang Penting. Kementerian Perdagangan.

Bradley, R., Pratt, R. M. E., Byrd, T. A \& Simmons, L. 2011. The Role of Enterprise Architecture in the Quest for it Value. MIS Quarterly Executive. 10 (2): 19-27.

Bradley, R. V., Pratt, R. M. E., Byrd, T. A., Outlay, C. N \& Wynn Jr, D. E. 2012. Enterprise architecture, IT effectiveness and the mediating role of IT alignment in US hospitals. Information Systems Journal. 22 (2): 97-127.

Daryanto, A. 2009. Dinamika Daya Saing Industri Peternakan. Bogor: IPB Press.

David, M. E., David, F. R \& David, F. R. 2016. The Quantitative Strategic Planning Matrix: a New Marketing Tool. Journal of Strategic Marketing. 25 (4): 342-352.

Deblitz, C., Charry, A. A \& Parton, K. A. 2005. Beef Farming Systems Across the World: an Expert Assessment from an International Cooperative Research Project (IFCN). Extention Farming Systems Journal. 12 (1): 1-14.

Dehbokry, G. S \& Chew, E. K. 2015. Developing Business Architecture for SMEs: a Strategic Tool for Capability Orchestration and Managing Dynamisms. Journal of Innovation Management in Small and Medium Enterprise. 2015: 1-9.

Ditjennak. 2014. Konsumsi Daging Segar Indonesia. Jakarta: Kementerian Pertanian.

Dugo, T. H. N. 2011. Arsitektur strategi PT Petrokimia Gresik 2010-2020. Tesis. Bogor: Institut Pertanian Bogor.

Farida, N. 2016. Determinants of Marketing Performance: Innovation, Market Capabilities and Marketing Performance. Jurnal Dinamika Manjemen. 7 (1): 59-65.

Fjeldstad, Ø. D., Snow, C. C., Miles, R. E \& Lettl, C. 2012. The Architecture of Collaboration. Strategic Management Journal. 33: 734-750.

GPMT. 2014. Harga Komoditi. Available at: www. asosiasi-gpmt.blogspot.co.id. August 19, 2017. 
Hamel, G \& Prahalad, C. K. 2000. Kompetisi Masa Depan; Strategi-strategi Terobosan untuk Merebut Kendali atas Industri Anda dan Menciptakan Pasar Masa Depan. Jakarta: Binarupa Aksara.

Kemendag. 2017. Peranan Infrastruktur dalam Rangka Meningkatkan Daya Saing Logistik Nasional. Available at: www.kemendag.go.id/pusdiklat/news/wawasan/32. August 19, 2017.

Krzyżanowska, M \& Tkaczyk, J. 2015. Redefening Products as a Positioning Strategy: a Case of the Partnership for Health. International Journal of Management Cases. 17: 81-97.

Marimin. 2004. Teknik dan Aplikasi: Pengambilan Keputusan Kriteria Majemuk. Jakarta: Grasindo.

Markovic, M. R. 2008. Effective Organizational Change Management. Serbian Journal of Management. 3 (1): 119-125.

McMillin, K. W., Lampila, L. E. Marcy, J. A. 2012. Traceability in the Meat, Poultry and Seafood Industries. pp 565-595. In: Kerry JP (ed.). Advances in Meat, Poultry and Seafood Packaging. Cambridge: Woodhead Publishing Limited.

Micah, B. M. 2011. An Analysis of the Broiler Supply Chain in Swaziland: A Case Study of Manzini Region. Asian Journal of Agricultural Science. 3 (6): 492-499.

Nurfadillah, S. 2015. Daya Saing Ayam Ras Pedaging di Indonesia dalam Menghadapi Masyarakat Ekonomi ASEAN. Tesis. Bogor: Institut Pertanian Bogor.

Palma, M. J. A., Neailey, K \& Roy, R. 2014. Business Process Re-Design Methodology to Support Supply Chain Integration. International Journal of Information Management. 34 (2): 167176.

Pefindo. 2009. Poultry Industry. Available at: http:// new.pefindo.com/files/id_poultry_200904. pdf. August 19, 2017.

Poultry Indonesia. 2016. Perunggasan Era MEA. Available at: http://www.poultryindonesia.com/ read-new/perunggasan-era-mea. March 25, 2016.

Pusdatin. 2015. Outlook Komoditas Daging Ayam 2015. Jakarta: Kementerian Pertanian.

Putri, V. W \& Yuniawan, A. 2016. Organizational Effectiveness: Social Capital and Competitive Advantage Approach. Jurnal Dinamika Manajemen. 7 (1): 76-90.
Putri, W. R., Samsusin, M. Rianto, E. Susilowati, I. 2017. Consumers' Willingness to Pay for Halal Labelled Chicken Meat. Jurnal Dinamika Manajemen. 8 (1): 122-133.

Rismon, B. 2010. Arsitektur strategik Perum Pegadaian. Tesis. Bogor: Institut Pertanian Bogor.

Saptana \& Daryanto, A. 2013. Dinamika Kemitraan Usaha Agribisnis Berdaya Saing dan Berkelanjutan. Pusat Sosial Ekonomi dan Kebijakan Pertanian. Badan Penelitian dan Pengembangan Pertanian. Kementerian Pertanian.

Saptana \& Sumaryanto. 2009. Kebijakan Antisipatif terhadap Peraturan dan Kebijakan Perunggasan Pemerintah DKI 2010. Pusat Analisis Sosial Ekonomi dan Kebijakan Pertanian. Analisis Kebijakan Pertanian. 7 (4): 319-335.

SIPD. 2016. Annual Report PT Sierad Produce Tbk. Available at: http://www.sieradproduce. com/EN/investor/document/Pages/AnnualReport.aspx. March 17, 2016.

Siebers, L. Q. Zhang, T \& Li, F. 2013. Retail Positioning through Customer Satisfaction: an Alternative Explanation to the ResourceBased View. Journal of Strategic Marketing. 21: 559-587.

Sugianto, L \& Hartono, S. 2017. Enhancing Capability of Human Resources Innovation. Jurnal Dinamika Manajemen. 8 (1): 108-121.

Tangendjaja, B. 2010. Global Competitiveness of Poultry Production in South East Asia. Badan Penelitian dan Pengembangan Pertanian. Kementerian Pertanian. Wartazoa. 20 (4): 307340

USDA. 2016. Livestock and Poultry: World Market and Trade. October 2016.

Widodo, A. E. 2008. Perumusan Arsitektur Strategik PT Sigma Utama Berbasis Kompetensi Inti. Tesis. Bogor: Program Pasca Sarjana Manajemen dan Bisnis Institut Pertanian Bogor

Windhorst, H. W. 2006. Changes in Poultry Production and Trade Worldwide. World's Poultry Science Journal. 62 (4): 585-602.

Yang, S \& Lynn, M. 2014. More Evidence Challenging the Robustness and Usefulness of the Attraction Efect. Journal of Marketing Research. 51: 508-513.

Yoshida, D. T. 2006. Arsitektur Strategik-Sebuah Solusi Meraih Kemenangan dalam Dunia yang Senantiasa Berubah. Jakarta: PT Elex Komputindo. 